\title{
A New Attitude-Behaviour (AB) Theory for Organizational Leadership
}

\author{
P. S. Aithal ${ }^{1} \&$ Shubhrajyotsna Aithal ${ }^{2 *}$ \\ ${ }^{1}$ Srinivas Institute of Management Studies, Srinivas University, Mangalore - 575 001, India \\ ${ }^{2}$ Faculty, College of Engineering \& Technology, Srinivas University, Mangalore, India \\ E-mail: shubhraaithal@gmail.com
}

Type of the Paper: Research Paper.

Type of Review: Peer Reviewed.

Indexed in: OpenAIRE.

DOI: http://doi.org/10.5281/zenodo.3248646.

Google Scholar Citation: IJMTS

How to Cite this Paper:

Aithal, P. S., \& Aithal, Shubhrajyotsna. (2019). A New Attitude-Behaviour (AB) Theory for Organizational Leadership. International Journal of Management, Technology, and Social Sciences (IJMTS), 4(1), 83-97.

DOI: http://doi.org/10.5281/zenodo.3248646.

International Journal of Management, Technology, and Social Sciences (IJMTS)

A Refereed International Journal of Srinivas University, India.

IFSIJ Journal Impact Factor for $2018=4.764$

(C) With Authors.

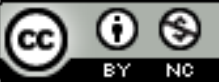

This work is licensed under a Creative Commons Attribution-Non Commercial 4.0 International License subject to proper citation to the publication source of the work.

Disclaimer: The scholarly papers as reviewed and published by the Srinivas Publications (S.P.), India are the views and opinions of their respective authors and are not the views or opinions of the SP. The SP disclaims of any harm or loss caused due to the published content to any party. 


\title{
A New Attitude-Behaviour (AB) Theory for Organizational Leadership
}

\author{
P. S. Aithal $^{1}$ \& Shubhrajyotsna Aithal $^{2 *}$ \\ ${ }^{1}$ Srinivas Institute of Management Studies, Srinivas University, Mangalore - 575 001, India \\ ${ }^{2}$ Faculty, College of Engineering \& Technology, Srinivas University, Mangalore, India \\ E-mail: shubhraaithal@gmail.com
}

\begin{abstract}
The organizational fate depends on a committed effective decision maker who can predict the future business situations based on various affecting parameters on the organizational business. The right decisions taken at right time can elevate an organization as a winning organization and the decision maker can transform himself as an acceptable leader. Such decisions can also decide the fate of the organization along with the livelihood of its employees. A winning leader is an asset of an organization and the employees are directly and indirectly get the benefits of such a leader. If the leader fails in predicting the future of a profit oriented organization or not for profit organizations, the employees are directly going to be the victims of such wrong decisions. Leaders should able to make a correct judgment while taking decisions based on effective predictions by using predictive analysis framework. The attitude of the leader plays an important role while making decisions on solving organizational/individual problems. In Simon's model of decision making, the attitude of the leader decides his ability to identify a problem, finding alternative solutions, analysing these alternatives to find optimum alternative, and finally to implement the best alternative to practically solve the problem. Attitude is the mental status of a human being which represents the emotions based on his/her feelings at a given time and controls his/her instantaneous behaviour. In this paper, we have developed a theory of winning leaders actions based on their behaviour in organizations. It is argued that the behaviour of a leader depends on his/her attitude which may be positive or negative depends on the four factors identified as feelings, emotions, belief, and environment. Thus a supportive, effective, good environment creates a positive attitude and hence winning leaders. The bad environment supports a negative attitude due to wrong belief, negative emotions, and frustrative feelings which are again depend on the present and past environment of the decision maker. The various components which are affecting leaders' environmental factor and their important characteristic elements are identified.
\end{abstract}

Keywords: AB Theory of Leadership, Attitude, Behaviour, Choice, and Decision.

\section{INTRODUCTION :}

An effective leader is the strength of an organization and his ability of making decisions related to the problems on short term and long term objectives of the organization decides the fate of the organization and hence the fate of the stakeholders. A committed leader in business organizations is an effective decision maker who can predict the future business situations based on various affecting parameters on the organizational business. Making right decisions at right time on organizational challenges can elevate an organization as winning organization and transform the decision maker into an acceptable leader. Making right decision in organizational and business environment depends on three factors (1) leaders personality and behaviour, (2) quality of the information related to the problem/challenge, and (3) the ability of the leader on predicting the future. 
Since the decisions taken by the leader decides the fate of the organization along with the livelihood of its employees and their dependent family members, the role of the leader is very challenging and risk taking. It is argued in many scholarly analysis that a winning leader is an asset of an organization and the employees are directly and indirectly get the benefits of such leader. If the leader fails in predicting the future of a profit oriented organization or not for profit organizations, the employees are directly going to be the victims of such wrong decisions. Thus an understanding leader who can be role model for every employee is important in every organization for sustainability for long time.

Leaders should able to make correct judgement while taking decisions based on his personal traits (personality), his attitude, and ability to make effective predictions by using predictive analysis framework. The attitude of the leader plays an important role while making decisions on solving organizational/individual problems. It is argued that the personality of a leader cannot be changed easily [1]. In Simon's model of decision making, the attitude of the leader decides his ability of identifying a problem, finding alternative solutions, analysing these alternatives to find optimum alternative, and finally to implement the best alternative to practically solve the problem. Thus identifying a problem is the behaviour of a leader and is important initial instinct and is depends on the attitude of a leader.

According to ABC model of attitude suggested by Eagly \& Chaiken 1993 \& Van den Berg et al. 2006 [2-3], human attitude as an object has three components identified as Affect (A), Behaviour (B) and Cognition (C). Affect component represents the individual's feelings about the object Attitude, Behaviour component represents the individual's intention towards the object Attitude, and Cognitive component represents the beliefs of an individual towards the object attitude.

But based on the observation and review of related works, we have developed an improved model on successful leadership for winning organizations which is based on Attitude and Behaviour of a leader called Attitude-Behaviour framework of Leadership. This model holds good for individual leadership and organizational leadership and describes how the past and present environment of a leader effects the present decisions on future performances of the organization for sustainability.

\section{RELATED WORKS :}

\subsection{Leadership Theories}

Many leadership theories are evolved during last 100 years. These theories are tried to explain the successful leadership qualities individually, working in teams, working in organizations and even working as leader in society. The important theories developed during last century with generality in their model include Great-man theory, Trait theory, Contingency or situational theory, Style and Behaviour theory, Process Leadership theory, Transactional leadership theory, etc. Table 1 contains some of general leadership theories developed during last century. These theories are framed based on certain characteristics of a leader while making decisions and certain nature of the leader towards the problems he faces in his life/organization/society. These theories focus on attitude of a leader and his behaviour towards making decisions.

Table 1 : Review of General leadership Theories and their focus

\begin{tabular}{|l|l|l|l|}
\hline S. No. & $\begin{array}{l}\text { Leadership } \\
\text { Theory }\end{array}$ & Focus & Reference \\
\hline 1 & Great-man Theory & Leader is born not made & $\begin{array}{l}\text { Thomas Carlyle } \\
\text { (1847) [4] }\end{array}$ \\
\hline 2 & Trait Theory & $\begin{array}{l}\text { Based on (i) emergent traits (those which are } \\
\text { heavily dependent upon heredity) as height, } \\
\text { intelligence, attractiveness, and self- } \\
\text { confidence and (ii) effectiveness traits (based }\end{array}$ & $\begin{array}{l}\text { Ekvall \& Arvonen, } \\
1991 \text { [5] }\end{array}$ \\
\hline
\end{tabular}


International Journal of Management, Technology, and Social

\begin{tabular}{|l|l|l|l|}
\hline & & $\begin{array}{l}\text { on experience or learning), including } \\
\text { charisma }\end{array}$ & \\
\hline 3 & $\begin{array}{l}\text { Contingency } \\
\text { Theories } \\
\text { (Situational) }\end{array}$ & $\begin{array}{l}\text { There is no single right leadership because } \\
\text { the internal and external dimensions of the } \\
\text { environment require the leader to adapt to } \\
\text { that particular situation }\end{array}$ & Greenleaf, 1977 [6] \\
\hline 4 & $\begin{array}{l}\text { Style and Behavior } \\
\text { Theory }\end{array}$ & $\begin{array}{l}\text { Leaders of three categories as democratic } \\
\text { leaders, autocratic leaders, and laissez-faire } \\
\text { leaders }\end{array}$ & Yukl (1989) [7] \\
\hline 5 & $\begin{array}{l}\text { Process Leadership } \\
\text { Theory }\end{array}$ & $\begin{array}{l}\text { Process theory focus on servant leadership, } \\
\text { principal centered leadership and charismatic } \\
\text { leadership }\end{array}$ & Greenleaf, (1996) [8] \\
\hline 6 & $\begin{array}{l}\text { Transactional } \\
\text { leadership Theory }\end{array}$ & $\begin{array}{l}\text { Type of contingent-reward leadership that } \\
\text { had active and positive exchange between } \\
\text { leaders and followers }\end{array}$ & $\begin{array}{l}\text { Bass and Avolio } \\
\text { (1994) [9] }\end{array}$ \\
\hline 7 & $\begin{array}{l}\text { Transformational } \\
\text { leadership Theory }\end{array}$ & $\begin{array}{l}\text { A transformational leader attempts to induce } \\
\text { followers to reorder their needs by } \\
\text { transcending self-interests and strive for } \\
\text { higher order needs. Such leaders empowers } \\
\text { the followers }\end{array}$ & $\begin{array}{l}\text { House \& Shamir, } \\
\text { (1993) [10] }\end{array}$ \\
\hline
\end{tabular}

Further specific leadership theories developed and tested during last 50 years are also listed in table 2 which also include some of the general leadership theories. The focus or the constructs of the theories are listed along with scholarly published references. These theories are build or developed based on the leaders attitude of seeing and understanding the problems or situations to
Make decisions and his behaviour towards individual or organizational or social problems. All leadership theories deal with the decision making abilities of a leader in internal or external environmental uncertainties. Thus the published work deals with mainly on the behaviour of a leader in a given environment.

Table (2.a) : Specific Leadership theories developed during last 50 years

\begin{tabular}{|l|l|l|l|}
\hline $\begin{array}{l}\text { S. } \\
\text { No. }\end{array}$ & $\begin{array}{l}\text { Type of leadership } \\
\text { Theories }\end{array}$ & Focus/ Constructs & Reference \\
\hline 1 & $\begin{array}{l}\text { Implicit leadership } \\
\text { Theories }\end{array}$ & $\begin{array}{l}\text { Individuals create cognitive representations } \\
\text { of the world, and use these preconceived } \\
\text { notions to interpret their surroundings and } \\
\text { control their behaviours. }\end{array}$ & $\begin{array}{l}\text { Offermann, L. R., } \\
\text { (1994) [11] }\end{array}$ \\
\hline 2 & $\begin{array}{l}\text { Managerial leadership } \\
\text { Theories }\end{array}$ & $\begin{array}{l}\text { Leader who engages in an influence process } \\
\text { for the purpose of helping others understand } \\
\text { what needs to be done, or that helps other } \\
\text { individuals or groups accomplish shared } \\
\text { objectives }\end{array}$ & $\begin{array}{l}\text { Yukl, G. (1989). } \\
\text { [12] }\end{array}$ \\
\hline 3 & $\begin{array}{l}\text { Transactional and } \\
\text { transformational leadership } \\
\text { theories }\end{array}$ & $\begin{array}{l}\text { Transactional leaders focus on organization, } \\
\text { supervision, and group performance, where } \\
\text { as transformational leaders focus on change } \\
\text { within the organization. }\end{array}$ & $\begin{array}{l}\text { Wofford, J. C., } \\
\text { (1994) [13] }\end{array}$ \\
\hline 4 & $\begin{array}{l}\text { Contingency leadership } \\
\text { Theory }\end{array}$ & $\begin{array}{l}\text { It claims that there is no best way to organize } \\
\text { a corporation, to lead a company, or to make } \\
\text { decisions. Instead, the optimal course of }\end{array}$ & $\begin{array}{l}\text { Yukl, G. (2011). } \\
\text { [14] }\end{array}$ \\
\hline
\end{tabular}




\begin{tabular}{|c|c|c|c|}
\hline & & $\begin{array}{l}\text { action is contingent (dependent) upon the } \\
\text { internal and external situation. }\end{array}$ & \\
\hline 5 & $\begin{array}{l}\text { Strategic Leadership } \\
\text { Theories }\end{array}$ & $\begin{array}{l}\text { It is the ability to influence others to } \\
\text { voluntarily make decisions that enhance the } \\
\text { prospects for the organisation's long-term } \\
\text { success while maintaining short-term } \\
\text { financial stability. }\end{array}$ & $\begin{array}{l}\text { Tone Hosmer, L. } \\
\text { (1982). [15] }\end{array}$ \\
\hline 6 & $\begin{array}{l}\text { Situational leadership } \\
\text { Theories }\end{array}$ & $\begin{array}{l}\text { It refers to when the leader or manager of an } \\
\text { organization must adjust his style to fit the } \\
\text { development level of the followers he is } \\
\text { trying to influence. }\end{array}$ & $\begin{array}{l}\text { Hersey, P., (1997) } \\
\text { [16] }\end{array}$ \\
\hline 7 & $\begin{array}{l}\text { Personality and charismatic } \\
\text { leadership }\end{array}$ & $\begin{array}{l}\text { Articulating a vision and mission, and } \\
\text { creating and maintaining a positive image in } \\
\text { the mind of followers }\end{array}$ & $\begin{array}{l}\text { House, R. J., } \\
\text { (1992) [17] }\end{array}$ \\
\hline 8 & $\begin{array}{l}\text { Distributed leadership } \\
\text { Theories }\end{array}$ & $\begin{array}{l}\text { It equates with shared, collective and } \\
\text { extended leadership practice that builds the } \\
\text { capacity for change and improvement. }\end{array}$ & $\begin{array}{l}\text { Barry, D. (1991) } \\
\text { [18] }\end{array}$ \\
\hline 9 & Shared leadership Theories & $\begin{array}{l}\text { It broadly distributes leadership } \\
\text { responsibility, such that people within a team } \\
\text { and organization lead each other. }\end{array}$ & $\begin{array}{l}\text { Pearce, C. L., } \\
\text { (2000) [19] }\end{array}$ \\
\hline 10 & $\begin{array}{l}\text { Servant leader } \\
\text { ship }\end{array}$ & $\begin{array}{l}\text { It is a philosophy and set of practices that } \\
\text { enriches the lives of individuals, builds better } \\
\text { organizations and ultimately creates a more } \\
\text { just and caring world. }\end{array}$ & $\begin{array}{l}\text { Van Dierendonck, } \\
\text { D. (2011). [20] }\end{array}$ \\
\hline 11 & $\begin{array}{l}\text { Clinical } \\
\text { leadership }\end{array}$ & $\begin{array}{l}\text { The concept of clinical healthcare staff } \\
\text { undertaking the roles of leadership: setting, } \\
\text { inspiring and promoting values and vision, } \\
\text { and using their clinical experience and skills } \\
\text { to ensure the needs of the patient }\end{array}$ & $\begin{array}{l}\text { Stanley, D. J. } \\
\text { (2012). [21] }\end{array}$ \\
\hline 12 & $\begin{array}{l}\text { Spiritual } \\
\text { leadership }\end{array}$ & $\begin{array}{l}\text { It is a holistic approach to leadership in } \\
\text { which the leader strives to encourage a sense } \\
\text { of significance and interconnectedness } \\
\text { among employees. }\end{array}$ & $\begin{array}{l}\text { Fry, L. W. (2003). } \\
\text { [22] }\end{array}$ \\
\hline
\end{tabular}

\subsection{Attitude-Behaviour Models :}

Attitude-behaviour relations model is initially systematically studied in social psychology by Ajzen I et al during 1977 [23]. According to this model, the attitudinal and behavioural entities consisting of four different elements namely (1) the action, (2) the target at which the action is directed, (3) the context in which the action is performed, and (4) the time at which the action is performed. The model predicts that behaviour is a monotonic function of attitudes and external conditions and that the strength of the attitudebehaviour relationship is a function of the strength of the external environment [24]. Ellis et. al [2] developed another ABC Model on human behaviour where - A stands for Antecedent (situation), B stands for Beliefs (thoughts of the situation/ interpretation of an event), and C stands for Consequences (outcome).

\section{OBJECTIVES :}

The paper is conceptual in nature and follows a research model of review based prediction and postulates based analysis to identify the suitable model in the form of a Theory to answer a question on what factors decides an acceptable leader in Winning Organizations. This also include :

(1) To identify a suitable reason for success of a 
leader in winning organizations

(2) To develop a suitable theory on Leaders' action called behaviour.

(3) To determine the underlying constructs of behaviour which decides the decision making characteristics of a leader in business organizations which a have a long term objectives.

(4) To analyse the developed model using ABCD listing.

(5) To suggest some recommendations to redefine the objectives of both winning organizations and loosing organizations.

\section{FACTORS AFFECTING THE} ATTITUDE :

The attitude of a person is determined by psychological factors like ideas, values, beliefs, perception, etc. All these have a complex role in determining a person's attitude. Aman Sharma, (2016) [25] identified eight factors responsible for the development of attitudes. These eight factors are (1) family, (2) peers, (3) conditioning, (4) social adjustment functions, (5) direct instruction, (6) modelling, (7) satisfaction of wants, and (8) prejudices. Another study [26] on factors influencing the attitude lists nine factors which are considered as (1) Social Factors, (2) Direct Instruction, (3) Family, (4) Prejudices, (5) Personal Experience, (6) Media, (7) Educational and Religious Institutions, (8) Physical Factors, and (9) Economic Status and Occupations.

\section{FACTORS AFFECTING THE BEHAVIOUR :}

Behaviour is the outcome of the attitude of a person. The behaviour of a leader in a given situation depends on the attitude of him. This is well known and the outcome of many psychological studies [1]. According to one school of thought, the four main factors that influence behaviour and performance are: Biographical and demographical characteristics, Intellectual and physical abilities, Self-concept and self-esteem, and Personality. As per another school of thought, the behaviour of a person depends on six factors : (1) Willpower, (2) Knowledge and skills, (3) Social motivation, (4) Social ability, (5) Structural motivation, and (6) Structural ability. The third school of thought includes three factors as (1) Personal factors, (2) Environmental factors, and (3) Organizational factors affect individual behaviour. Finally, it is also argued that the following five factors affect the behaviour of a leader which include : (1) Personality, (2) Situation, (3) Needs, (4) Leadership style, and (5) Operating environment.

\section{ATTITUDE-BEHAVIOUR MODEL OF LEADERSHIP :}

Attitude is the mental status of a human being which represents the emotions at a given time and controls his/her instantaneous behaviour. Such behaviour reflects in instantaneous decision making of a leader.

\subsection{Postulates of Attitude-Behaviour Model :}

It can be argued that the behaviour of a human being depends on his/her attitude and the attitude depends on his or her feelings at that time which in turn depends on the emotions of the person. It can be argued that the emotions of a person depend on his/her beliefs on the situation. It is also known that the belief of a person is strongly depending on the environment around him during his present and past life. Accordingly, we propose the following postulates :

(1) Personality cannot be changed so easily, but behaviour of a person can be changed.

(2)The behaviour of a leader depends on his attitude.

(3) The attitude of the leader depends on his feelings.

(4) The feelings of a leader depend on his emotions.

(5) The emotions of a leader mostly depend on his beliefs.

(6) The belief of a leader depends on his present and past environment. 
(Behaviour $)=>($ Attitude $)=>($ Feelings $)=>($ Emotions $)=>($ Beliefs $)=>($ Environment $)$
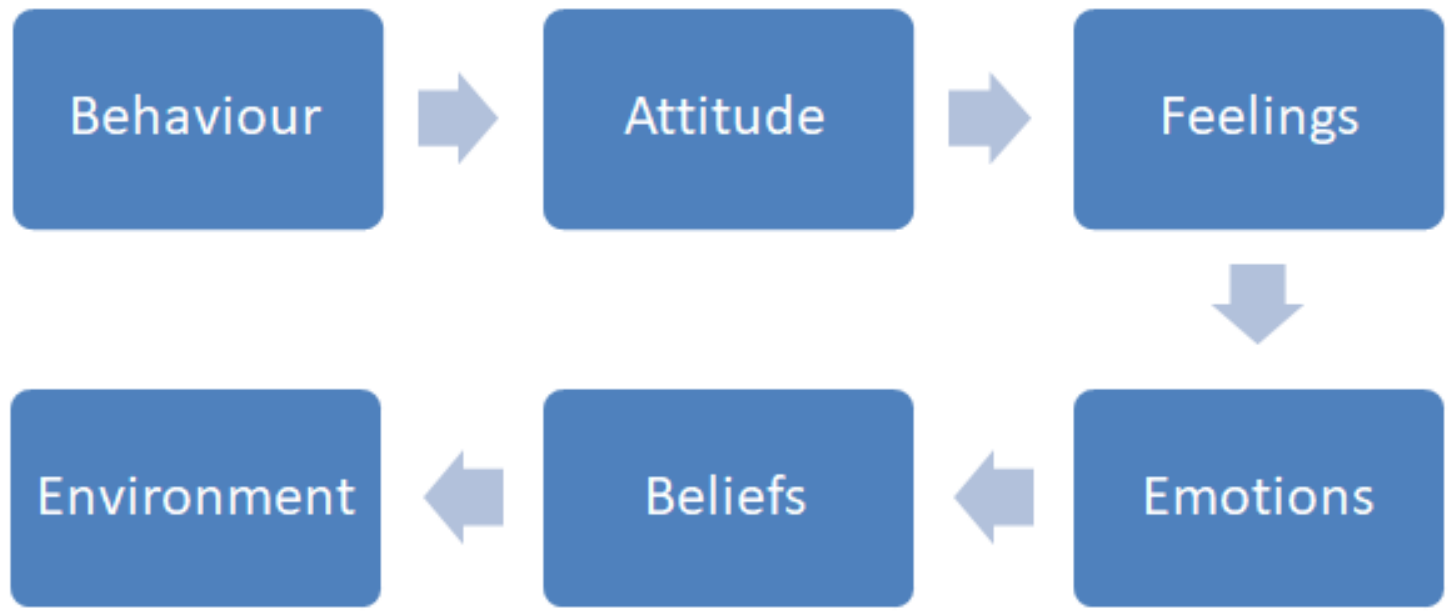

Fig. 1 : Block diagram representing depending factors of Attitude and behaviour of a leader

\subsection{Leadership and decision making :}

A winning leader will make winning decisions by rightly analysing the situations to predict the future state of affairs. According to our theory of leadership, the behaviour (action) of a leader to solve an identified problem depends on his attitude. Hence the theory is called attitudebehaviour theory, which states that the behaviour of a leader depends on his attitude towards solving a problem or making a decision which further depends on his feelings, emotions, beliefs, and hence his present and past environment. The constructs of AttitudeBehaviour (AB) model are :

\section{(1) Attitude :}

Attitude is a tendency to act in a certain way, either favorably or unfavorably concerning objects, people, or events. Attitude of a person depends on how a person feels about a situation or an issue. It expresses an individual's positive or negative feeling about an object or a situation. Attitude of a person towards a given situation can be measured by measuring and understanding his feelings, and thoughts by asking questions to a person one can measure his feelings and thoughts. In general, if a person has a positive attitude about his work responsibilities, it will be reflected by good work performance, less absenteeism, less turnover, obedience towards rule or authority, etc. If a person has got a negative attitude towards his work responsibilities, he will act in exactly the opposite way. The negative attitude can be changed by simple persuasion or by training and coaching. Attitude is an abstract learned reaction and as per our postulate, it heavily depends on the feeling of a leader towards an object or an issue.

\section{(2) Behaviour :}

As mentioned earlier, behaviour is the outcome of the attitude of a person. The behaviour of a leader on a given situation depends on the attitude of him. This is well known and the outcome of many psychological studies. Behaviour can be measured by understanding the attitude of a person either by observing the actions or simply by asking questions to him about how he would behave in a particular situation. Behaviour is the action performed by a person based on his attitude towards an object or an issue. As per our postulate behaviour of a leader depends on his attitude. Hence by improving the attitude, the behaviour can be improved.

\section{(3) Feelings :}

In psychology, the word is usually reserved for the conscious subjective experience of emotion. Feelings are also known as a state of consciousness, such as that resulting from emotions, sentiments or desires. Feeling is an internal state of affair of a human being. As per our postulate, feelings of a leader depend on his 
emotions.

\section{(4) Emotions :}

Emotion is considered as the feedback of feeling. Emotion is the external state of affair of a human being. Emotions are mental states of readiness that arise from appraisals of events or one's

own thoughts. It is argued that emotions are eventdriven, while feelings are learned behaviours that are usually in hibernation until triggered by an external event. Unlike feeling, an emotion involves little cognitive awareness. As per our postulate emotion of a leader depends on his beliefs about that event or issue or object.

\section{(5) Beliefs :}

Belief of a person depends on what he follows with or without any reason. Beliefs of a leader are distinguished into three types as : (1) behavioural beliefs, which are assumed to influence attitudes toward the behaviour, (2) normative beliefs, which constitute the underlying determinants of subjective norms, and (3) control beliefs, which influence perceived behavioural control. As per the postulate of our attitude-behaviour theory, belief of a leader depends on his present and past environment.

(6) Environment (Past \& Present) :

The operating environment around a leader supports for risk taking and is motivating and encouraging creativity and allowing appropriate flexibility, rather than with rigidity and inflexibility. The environment which affects the attitude of a leader through his beliefs has various components (figure 3 ). The important components which decide the attitude of a leader are (1) Individual maturity of generous thinking which may have positive or negative effects as a positive thinker or negative thinker respectively.

(2) Living place and the country situation which may have positive impact or negative impact. (3) Family culture and tradition has mainly positive impact. (4) Organizational atmosphere which may have positive or negative impact. (5) Competing situations internally or externally in the organization which is against organizational objectives or individual objectives of a leader.

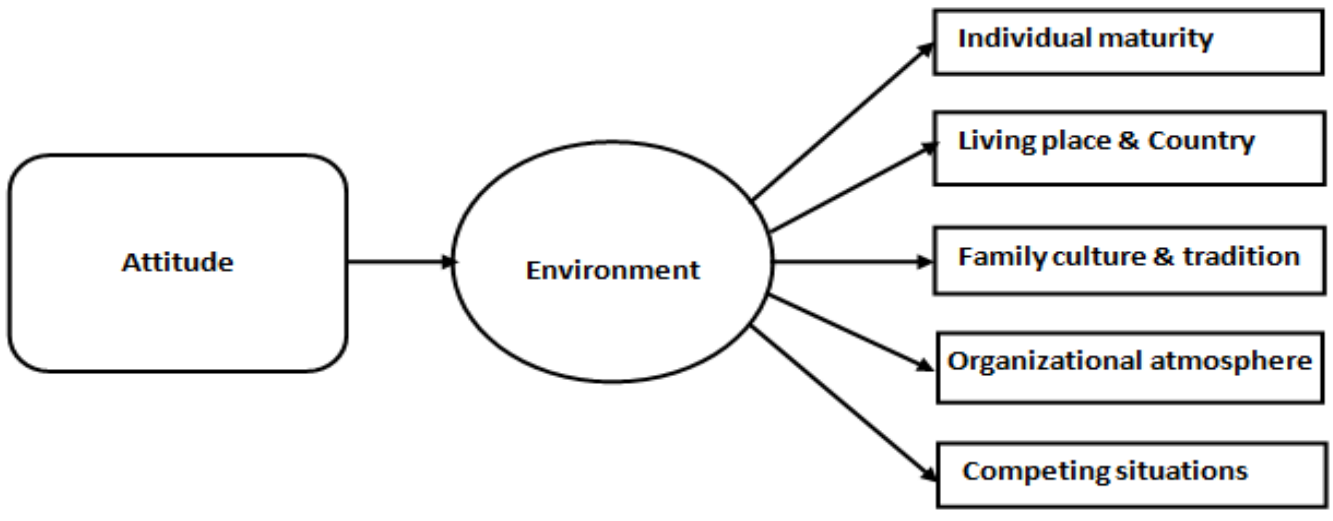

Fig. 2 : Components of environment which effects the leaders' attitude

The important environmental components which affects the belief and hence the attitude of a leader and hence affects his behaviour are discussed below and some of the important characteristic elements of these components are listed in table 3 :

(1) Impact of Individual Maturity for effective Leader :

Leadership maturity is a leader's ability to engage consistently with others who are the stakeholders of the organization. Individual maturity demands the ability to make wise and appropriate judgments about different problems. Usually, the leadership maturity is decided based on certain parameters like (1) relevance to time, place and person, (2) productive in terms of contributions made, and (3) uplifting in such way that interactions are positive, fulfilling, and enriching. Acquiring leadership maturity is a lifelong process and involves various stages. In each stage of developing maturity, leaders will develop a corresponding identity. Based on how 
a leader process life events and experiences, he may spiral upwards to higher maturity or downwards to lower maturity. Sometimes, they may also get stuck at one level for the rest of their life.

(2) Impact of Living place \& Country on effective Leader:

The environment in living place and the people in the surroundings also play an important role in developing the characteristics of a leader. Positive and encouraging atmosphere in home and surroundings will cultivate positive, generous feeling within a leader. Family stress may affect the decision making ability of a leader and such cases may create a catastrophic outcome in organizational performance. Similarly, the political and economical environment of the country and its impact on organizational performance or on society also affects the decision making ability of the leader.

(3) Impact of Family culture \& tradition on effective Leader:

Culture plays a primary role on the person's perception of the world. Many studies have shown that people from different cultures perceive things differently. Perception is the process by which we become aware of our environment. Culture and perception are closely related because it is through their own culture that people view and perceive themselves and others in the environment. The application of a leadership style cannot be an imposition but needs to consider the diversity of cultures in order to be effective. Although we live in a globalized economy in which everything is standardized, it is unlikely to find a generalization of the way culture influences leadership perception and execution.

(4) Impact of Organizational atmosphere on effective Leader:

Organizational business, opportunities, and culture also effect and makes an impact on a leader's ability and quality. It also improves the confidence of a leader for further innovation. A positive organizational atmosphere supports the leader for taking winning decisions. Stakeholders view on the organization or society in that country enhances or suppresses the confidence and risk taking ability of a leader.

(5) Impact of competing situations on effective Leader:

Both internal and external competition affects the strategic thinking ability of a leader. Competition may have either positive or negative effect on leaders decision making ability based on his personality, which depends on his attitude and hence his feelings, emotions, and belief. Positive leaders turn difficult situations into engaging learning moments whereas negative leaders convert challenges into unsolved problems.

Table 3 : Components of Environmental factor and their important characteristic elements

\begin{tabular}{|l|l|l|}
\hline S. No. & \multicolumn{1}{|c|}{$\begin{array}{c}\text { Components of Environmental } \\
\text { factor }\end{array}$} & \multicolumn{1}{c|}{ Characteristic elements } \\
\hline 1 & $\begin{array}{l}\text { Individual maturity of generous } \\
\text { thinking }\end{array}$ & $\begin{array}{l}\text { (1) Age } \\
\text { (2) Education } \\
\text { (3) Responsibility has taken } \\
\text { (4) Challenges faced }\end{array}$ \\
\hline 2 & $\begin{array}{l}\text { Living place and the country } \\
\text { situation }\end{array}$ & $\begin{array}{l}\text { (1) Peace in home } \\
\text { (2) Peace in neighborhood } \\
\text { (3) Facilities during childhood } \\
\text { (4) Country situation (social \& political) }\end{array}$ \\
\hline 3 & Family culture and tradition & $\begin{array}{l}\text { (1) Home culture } \\
\text { (2) Parents \& Family members attitude } \\
\text { (3) Religion culture \& tradition } \\
\text { (4) School studies with teachers \& friends attitude }\end{array}$ \\
\hline 4 & Organizational atmosphere & $\begin{array}{l}\text { (1) Nature of employees } \\
\text { (2) Type of business \& its connectedness with the } \\
\text { leader }\end{array}$ \\
\hline
\end{tabular}




\begin{tabular}{|l|l|l|}
\hline & & $\begin{array}{l}\text { (3) Opportunities expansion \& growth } \\
\text { (4) Current status of organizational business }\end{array}$ \\
\hline 5 & $\begin{array}{l}\text { Competing situations internally or } \\
\text { externally in the organization }\end{array}$ & $\begin{array}{l}\text { (1) Competing organizations } \\
\text { (2) Status of the organization in its environment } \\
\text { (3) Environmental situations for the business } \\
\text { (4) Internal and external strategies followed }\end{array}$ \\
\hline
\end{tabular}

\section{HOW TO DEVELOP A WINNING LEADER?}

A winning leader will have a positive attitude so that he will take winning decisions through his appropriate and acceptable behaviour. The positive attitude is always derived from his feelings about the problem or situation which may be positive or negative. These situational feelings depend on his emotions which in turn depend on his beliefs in life and about the situation/problem. But the belief of every person depends on his past and present environment where he has cultivated such belief. By changing the environment of a leader, his beliefs, and hence his emotions, and hence his feelings can be changed which in turn change his attitude and hence his behaviour. This may modify his ability to understand the problem, analysing the situation, and to make a sound decision. Thus the leader's problem solving and decision making ability can be improved by providing a positive atmosphere, trouble free supportive environment which supports positive feelings and hence winning attitude. Leaders may fail due to wrong decisions which are mainly due to their wrong attitude towards the problem. Such wrong attitude makes them to work less on studying the situations on the problem, identifying the possible solutions, analysing the solutions by predicting the future based on individual possible solutions and ability to do optimum decision. Winning leader works effectively on a problem based on his attitude towards the problem and ensures winning decisions.

8. QUALITATIVE ANALYSIS OF AB THEORY OF LEADERSHIP USING ABCD LISTING FRAMEWORK :

In this section, the Attitude-Behaviour theory is further analysed using qualitative $\mathrm{ABCD}$ analysis framework [27-50] where the advantages, benefits, constraints, and disadvantages of the theory from all stakeholders reference are listed.

\subsection{Advantages of AB Theory :}

(1) Gives an idea of how to develop a leader and how to improve the quality of his decisions.

(2) Confidence to make Decision of a leader is dependent quantity, not independent quantity (as postulated in Great man theory).

(3) Based on developed postulates of the theory, the constructs like feelings, emotions, belief, and environment of leader, which affects the attitude are mainly dependent variables and hence can be controllable.

(4) The theory gives an opportunity to improve the quality of a leader and hence the quality of decisions by identifying the components which are the constructs of leaders' environment.

(5) The components of leaders' environment which affects the attitude are mainly dependent variables and hence can be controllable.

\subsection{Benefits of AB Theory :}

(1) Behavioural modifications are possible by focussing on beliefs which depends on past and present environment.

(2) Attitude of a leader can be changed so that leaders can be made instead of born.

(3) The quality of decisions the leaders make can be improved by changing the attitude of a leader.

(4) The performance of a leader is better if he has a better past and present experience in his environment.

(5) The performance of the organizations and hence the fate of employees can be made certain by choosing a leader with a positive attitude.

\subsection{Constraints of AB Theory :}

(1) Since attitude is an intangible factor, controlling it is difficult.

(2) There may be some other unknown factors affecting the behaviour other than attitude.

(3) Controlling environmental components is 
difficult.

(4) The intensity of the environmental components on deciding the belief, emotion, feelings and hence attitude is different for different leaders and is dependent on their personality.

\subsection{Disadvantages of AB Theory :}

(1) The theory has taken only attitude as the main factor which modifies the behaviour of the leader while handling situations. Heredity based physical \& confidence factors may also affect the leaders' decision.

(2) Past experience cannot be changed so that improving environmental experience is possible only by changing present environmental experience.

\section{RECOMMENDATIONS :}

According to Attitude-Behaviour (AB) theory of leadership, the behaviour of a leader in any situation in organizations (organizational leader) or in society (individual or political leader) depends on his attitude to see and understand the problem. But the attitude on the problem and its solution including quick or delayed decision, nature of the decision and the handling of the consequences of the decision by the leader depends on the four factors identified as feelings, emotions, belief, and past \& present environment. Based on such postulates following suggestions are proposed as recommendations :

(1) A winning leader will have a positive attitude and is reflected by his behaviour while handling situations. Thus, attitude and behaviour are directly related. By changing the attitude, behaviour can be improved.

(2) Attitude is the mental status of a human being which represents the emotions based on his/her feelings at a given time and controls his/her instantaneous behaviour.

Table (2.a) : Summary of Leadership theory developed in this work (Continuation of table 2)

\begin{tabular}{|l|l|l|l|}
\hline $\begin{array}{l}\text { S. } \\
\text { No. }\end{array}$ & $\begin{array}{l}\text { Type of leadership } \\
\text { Theories }\end{array}$ & Focus/ Constructs & Reference \\
\hline 13 & $\begin{array}{l}\text { Attitude-Behaviour Theory } \\
\left(21^{\text {st }} \text { Century Leadership }\right. \\
\text { theory) }\end{array}$ & $\begin{array}{l}\text { The attitude of the leader controls their } \\
\text { behaviours and impacts on their } \\
\text { instantaneous decision. Attitude depends on } \\
\text { the four factors identified as feelings, } \\
\text { emotions, belief, and environment. }\end{array}$ & $\begin{array}{l}\text { Aithal P.S., } \\
\text { (2019) } \\
\text { [Present work] }\end{array}$ \\
\hline
\end{tabular}

(3) As per AB theory, winning leaders actions are based on their behaviour in organizations.

(4) The behaviour of a leader depends on his/her attitude which may be positive or negative depends on the four factors identified as feelings, emotions, belief, and environment.

(5) A supportive, effective, good environment creates a positive attitude and hence winning leaders. The bad environment supports a negative attitude due to wrong belief, negative emotions, and frustrative feelings which are again depend on the present and past environment of the decision maker.

(6) It is the responsibility of direct stakeholders of the organization to create a positive environment in the organization to allow their leader to think positively and to develop a positive attitude to behave (on a problem/situation) effectively to get an optimum winning solution.

(7) The components of environment which affect the leaders' attitude are identified. By focussing on improving or positive aspects of these components, leader can have peace of mind and positive mindset in terms of his attitude towards solving any problem optimally. By improving (i) maturity of generous thinking through proper education, (ii) identifying suitable living place and good people in the surroundings, (iii) making to involve in family culture \& tradition, (iv) cultivating positive, encouraging atmosphere in organization, and (v) seeking competitions in the organizational business, Leaders attitude and hence effective decision making behaviour can be improved.

This modified theory of leadership called Attitude-Behaviour (AB) theory is further summarized and added to the table 2 as table $2 \mathrm{a}$. 


\section{CONCLUSIONS :}

Based on reviewing related research, it is concluded that the attitude is the central characteristics of a leader and decides his behaviour in a given situation in an organization. Based on our postulates, the behaviour of a leader while reacting or responding to a situation depends on his attitude towards the problem, which in turn, depends on the feelings, emotions, and beliefs. It is also argued that the belief and hence feelings of a leader mainly depends on his present and past environment where he has grown and learned the life skills. Based on these aspects, we have developed a theory on winning leaders actions and their behaviour in organizations. It is argued that the behaviour of a leader depends on his/her attitude which may be positive or negative depends on the four factors identified as feelings, emotions, belief, and environment. Thus a supportive, effective, good environment creates a positive attitude and hence winning leaders. The bad environment supports a negative attitude due to wrong belief, negative emotions, and frustrative feelings which are again depend on the present and past environment of the leader.

\section{REFERENCES :}

[1] Conger, J. A., \& Kanungo, R. N. (1992). Perceived behavioural attributes of charismatic leadership. Canadian Journal of Behavioural Science/Revue canadienne des sciences du comportement, 24(1), 86.

[2] Eagly, A.H. \& Chaiken, S., 1993. The psychology of attitudes, Fort Worth, TX: Harcourt Brace Jovanovich.

[3] Van den Berg, H. et al., 2006. The impact of affective and cognitive focus on attitude formation. Journal of Experimental Social Psychology, 42(1), 373-379.

[4] Carlyle, T. (1847). Past and Present and Chartism. Wiley and Putnam.

[5] Ekvall, G., \& Arvonen, J. (1991). Changecentered leadership: An extension of the twodimensional model. Scandinavian Journal of Management, 7(1), 17-26.

[6] Greenleaf, Robert K. 1977. Servant
Leadership: A Journey into the Nature of Legitimate Power and Greatness. New York, NY: Paulist Press.

[7] Yukl, G. (1989). Managerial leadership: A review of theory and research. Journal of management, 15(2), 251-289.

[8] Greenleaf, R. K. (1996). On becoming a servant leader (D. M. Frick \& L.C. Spears, Eds.). San Francisco: Jossey - Bass.

[9] Bass, B. M., \& Avolio, B. J. (1994). Transformational leadership and organizational culture. The International Journal of Public Administration, 17(3-4), 541-554.

[10] House, R. J., \& Shamir, B. (1993). Toward the integration of transformational, charismatic, and visionary theories. In M. M. Chemers \& R. Ayman (Eds.), Leadership theory and research: Perspectives and directions (pp. 81-107). San Diego, CA, US: Academic Press.

[11] Offermann, L. R., Kennedy Jr, J. K., \& Wirtz, P. W. (1994). Implicit leadership theories: Content, structure, and generalizability. The leadership quarterly, 5(1), 43-58.

[12] Yukl, G. (1989). Managerial leadership: A review of theory and research. Journal of management, 15(2), 251-289.

[13] Wofford, J. C., \& Goodwin, V. L. (1994). A cognitive interpretation of transactional and transformational leadership theories. The Leadership Quarterly, 5(2), 161-186.

[14] Yukl, G. (2011). Contingency theories of effective leadership. The SAGE handbook of leadership, 24(1), 286-298.

[15] Tone Hosmer, L. (1982). The importance of strategic leadership. Journal of Business Strategy, 3(2), 47-57.

[16] Hersey, P., \& Blanchard, K. H. (1997). Situational leadership. In DEAN'S FORUM (Vol. 12, No. 2, p. 5).

[17] House, R. J., \& Howell, J. M. (1992). Personality and charismatic leadership. The Leadership Quarterly, 3(2), 81-108.

[18] Barry, D. (1991). Managing the bossless 
team: Lessons in distributed leadership. Organizational dynamics, 20(1), 3147.

[19] Pearce, C. L., \& Sims, H. P. (2000). Shared leadership: Toward a multi-level theory of leadership. In Advances in interdisciplinary studies of work teams (pp. 115-139). Emerald Group Publishing Limited.

[20] Van Dierendonck, D. (2011). Servant leadership: A review and synthesis. Journal of management, 37(4), 1228-1261.

[21] Stanley, D. J. (2012). Clinical leadership and innovation. Journal of Nursing Education and Practice, 2(2), 119.

[22] Fry, L. W. (2003). Toward a theory of spiritual leadership. The leadership quarterly, 14(6), 693-727.

[23] Ajzen I, Fishbein M. (1977). Attitudebehaviour relations: a theoretical analysis and review of empirical research. Psychological Bulletin, 84(5), 888-918.

[24] Gregory A. Guagnano, Paul C. Stern, Thomas Dietz (1995). Influences on Attitude-Behaviour Relationships: A Natural Experiment with Curbside Recycling. Environment \& Behaviour, 27(5), 699-718.

[25] Aman Sharma, (2016). 8 Factors Responsible for Development of Attitudes. http://www.psychologydiscussion.net/attitudes/8 -factors-responsible-for-development-ofattitudes/696. Downloaded on 01/04/2019.

[26] Factors Influencing Attitude. https://iedunote.com/factors-influencingattitude. Accessed on 01/.04/2019.

[27] Aithal, P. S., V.T. Shailashree, P. M. Suresh Kumar (2015). A New ABCD Technique to Analyze Business Models \& Concepts. International Journal of Management, IT and Engineering (IJMIE), 5(4), 409 - 423. DOI : http://doi.org/10.5281/zenodo.61652,

[28] Aithal, P. S., Shailashree V. T. \& Suresh Kumar P.M. (2016). Factors \& Elemental Analysis of Six Thinking Hats Technique using ABCD Framework. International Journal of Advanced Trends in Engineering and
Technology (IJATET),1(1), 85-95. DOI: http://doi.org/10.5281/zenodo.240259.

[29] Aithal, P. S. (2017). Factor Analysis based on ABCD Framework on Recently Announced New Research Indices. International Journal of Management, Technology, and Social Sciences (IJMTS), 1(1), 82-94. DOI: http://dx.doi.org/10.5281/zenodo.584105.

[30] Aithal, P. S., (2016). Study on ABCD Analysis Technique for Business Models, business strategies, Operating Concepts \& Business Systems, International Journal in Management and Social Science, 4(1), 98-115. DOI : http://doi.org/10.5281/zenodo.161137.

[31] Varun Shenoy, \& Aithal P. S., (2016). ABCD Analysis of On-line Campus Placement Model. IRA-International Journal of Management \& Social Sciences, 5(2), 227-244. DOI: http://dx.doi.org/10.21013/jmss.v5.n2.p3.

[32] Aithal, P. S. \& Suresh Kumar, P. M. (2016). CCE Approach through ABCD Analysis of 'Theory A' on Organizational Performance. International Journal of Current Research and Modern Education (IJCRME), 1(2),169-185. DOI: http://dx.doi.org/10.5281/zenodo.164704.

[33] Aithal, P. S., Shailashree V. T. \& Suresh Kumar P. M., (2016). Analysis of ABC Model of Annual Research Productivity using ABCD Framework. International Journal of Current Research and Modern Education (IJCRME), 1(1), 846-858. DOI http://doi.org/10.5281/zenodo.62022.

[34] Shubhrajyotsna Aithal \& Aithal P. S., (2016). ABCD analysis of Dye doped Polymers for Photonic Applications. IRA-International Journal of Applied Sciences, 4(3), 358-378. DOI : http://doi.org/10.5281/zenodo.155103. DOI : http://dx.doi.org/10.21013/jas.v4.n3.p1.

[35] Aithal, P. S., Shailashree, V. T. \& Suresh Kumar, P.M. (2016). The Study of New National Institutional Ranking System using ABCD Framework. International Journal of Current Research and Modern Education (IJCRME), 1(1), 389 - 402. DOI : http://doi.org/10.5281/zenodo.161077.

[36] Aithal, P. S., Shailashree, V.T.\& P.M. 
Suresh Kumar, Application of ABCD Analysis Framework on Private University System in India. International Journal of Management Sciences and Business Research (IJMSBR), 5(4), 159-170. DOI : http://doi.org/10.5281/zenodo.1 $\underline{61111 .}$

[37] Varun Shenoy \& Aithal, P. S. (2017). Quantitative ABCD Analysis of IEDRA Model of Placement Determination. International Journal of Case Studies in Business, IT and Education (IJCSBE), 1(2), 103-113. DOI: http://dx.doi.org/10.5281/zenodo.1133691.

[38] Aithal, P. S., Shailashree, V. T. \& Suresh Kumar, P. M. (2016). Analysis of NAAC Accreditation System using ABCD framework. International Journal of Management, IT and Engineering (IJMIE), 6(1), 30-44. DOI : http://doi.org/10.5281/zenodo.154272.

[39] Aithal, P. S., Shailashree, V. T. \& Suresh Kumar, P. M. (2016). ABCD analysis of Stage Model in Higher Education. International Journal of Management, IT and Engineering (IJMIE), 6(1), 11-24. DOI : http://doi.org/10.5281/zenodo.154233.

[40] Architha Aithal, and Aithal, P. S. (2017). ABCD Analysis of Task Shifting - An optimum Alternative Solution to Professional Healthcare Personnel Shortage. International Journal of Health Sciences and Pharmacy (IJHSP), 1(2), 36-51.DOI:

http://dx.doi.org/10.5281/zenodo.1038975.

[41] Aithal, P. S. (2017). ABCD Analysis as Research Methodology in Company Case Studies. International Journal of Management, Technology, and Social Sciences (IJMTS), 2(2), 40-54.

DOI:

http://dx.doi.org/10.5281/zenodo.891621.

[42] Aithal, P. S. (2016). Student Centric Curriculum Design and Implementation Challenges \& Opportunities in Business Management \& IT Education. IRA International Journal of Education and Multidisciplinary Studies, 4(3), 423-437. DOI : http://dx.doi.org/10.21013/jems.v4.n3.p9.

[43] Shubrajyotsna Aithal \& Aithal, P. S., (2016). Student Centric Learning Through
Planned Hardwork - An Innovative Model. International Journal of Scientific Research and Modern Education (IJSRME),1(1),886-898. DOI: http://doi.org/10.5281/zenodo.61830.

[44] Aithal, P. S., P. M. Suresh Kumar and Deekshitha, (2015). Societal Expectation and Institutional Accountability in Higher Education. International Journal of Management, IT and Engineering (IJMIE), 5(7), 361-373. DOI : http://doi.org/10.5281/zenodo.267021.

[45] Aithal, P. S., Suresh Kumar, P. M., and Pavithra Kumari, (2015). Methods and Approaches for Employability Skill Generation in Higher Educational Institutions. International Journal of Management, IT and Engineering (IJMIE), 5(7), 390-410. DOI: http://doi.org/10.5281/zenodo.267044.

[46] Aithal, P. S.,Shailashree V. T., \& P.M. Suresh Kumar, (2015) Application of ABCD Analysis Model for Black Ocean Strategy. International Journal of Applied Research (IJAR), 1(10), 331 - 337, DOI : http://doi.org/10.5281/zenodo.163424.

[47] Aithal, P. S. \& Suresh Kumar, P.M. (2016). Analysis of Choice Based Credit System in Higher Education. International Journal of Engineering Research and Modern Education (IJERME),1(1), 278-284. DOI: http://doi.org/10.5281/zenodo.161046.

[48] Krishna Prasad \& Aithal P. S. (2018). ABCD Analysis of Fingerprint Hash Code, Password and OTP based Multifactor Authentication Model. Saudi Journal of Business and Management Studies, 3(1), 65-80. DOI: http://doi.org/10.21276/sjbms.2018.3.1.10.

[49] Aithal P. S. \& Architha Aithal (2018). The Concept and Importance of Alternative Strategy as Parallel Strategy to be followed in Organizational Decisions to Ensure Success. International Journal of Management, Technology, and Social Sciences (IJMTS), 3(2), 1-15. DOI : http://doi.org/10.5281/zenodo.130 2779.

[50] Aithal P. S. \& Shubhrajyotsna Aithal, (2018). Factor \& Elemental Analysis of Nanotechnology as Green Technology using 
International Journal of Management, Technology, and Social

ABCD Framework. International Journal of Management, Technology, and Social Sciences (IJMTS), 3(2), 57-72. DOI : https://doi.org/10.5281/zenodo.1451490. 